\title{
Standardization of Optimum Season for Softwood Grafting in Guava (Psidium guajava L.) cv. Sardar
}

\author{
B. Manga*, P. Jholgiker, G.S.K. Swamy, G. Prabhuling and N. Sandhyarani \\ Department of Fruit Science, KRCCH, Arabhvi, University of Horticultural Sciences, \\ Bagalkot, India \\ *Corresponding author:
}

\begin{tabular}{|c|c|}
\hline & A B S T R A C T \\
\hline Keywords & $\begin{array}{l}\text { An experiment was conducted to standardization the optimum season for softwood } \\
\text { grafting in guava (Psidium guajava L.) cv. Sardar at the Department of Fruit }\end{array}$ \\
\hline $\begin{array}{l}\text { Guava, Softwood } \\
\text { grafting, Season, } \\
\text { Graft success }\end{array}$ & $\begin{array}{l}\text { Science, Kittur Rani Channamma College of Horticulture, Arabhavi, University of } \\
\text { Horticultural Sciences, Bagalkot, during the period of } 2012-2013 \text {. Softwood } \\
\text { grafting was performed at monthly interval from July to December months under }\end{array}$ \\
\hline Article Info & shadehouse ecosystem significantly highest percentage of graft success was \\
\hline $\begin{array}{l}\text { Accepted: } \\
26 \text { April } 2017 \\
\text { Available Online: } \\
10 \text { May } 2017\end{array}$ & $\begin{array}{l}\text { Growth attributes like, number of sprouts, length of sprout, percent sprouting and } \\
\text { number of leaves also registered maximum values in graft prepared in the month } \\
\text { of December. }\end{array}$ \\
\hline
\end{tabular}

\section{Introduction}

Guava (Psidium guajava L.) is one of the most promising fruit crops of India and is considered as one of the nutrionally valuable and remunerative crops (Singh et al., 2007). Guava fruits are used for both, fresh consumption and processing. In the recent years, guava is gaining popularity in the international trade due to its nutritional value and processed products (Singh et al., 2005). Non-availability of quality of planting materials and consequent substitution of poor quality seedling has adversely affected the guava production and productivity (Singh et $a l ., 2005)$. In view of the high return and the potential for processing, there is tremendous scope for bringing substantial additional area under guava crop in India. Hence there is a need to standardize rapid and successful propagation technique to meet the demand of genuine planning material of elite varieties through-out the year. Softwood grafting is one of commercial method of propagation followed in different fruit crops like mango (Amin, 1974), sapota (Pampanna and Sulkieri, 2000), custard apple (Chovatia and Singh, 1999) etc. Softwood grafting method becomes important when planting materials mother plants are limited as this method has tremendous potential for rapid multiplication. Guava also responds well for softwood grafting with varying degree of success from place to place (Shashikumar, 2010), 
indicating the influence of environment of success rate of softwood grafting in guava. One of the pre-requisite to realize high grafting success is identification and performance of grafting in correct season (Shashikumar, 2010). Keeping the above fats in view an experiment was carried out to identify suitable period for softwood grafting in guava.

\section{Materials and Methods}

An experiment, on standardization of optimum season for softwood grafting in guava (Psidium guajava L.) cv. Sardar was carried out during the period of 2012 to 2013, at the Department of Fruit Science, Kittur Rani Channamma College of Horticulture, Arabhavi, University of Horticultural Sciences, Bagalkot, Karnataka state. The experiment was laid out in Completely Randomized Design with 6 treatments and 4 replications. Hundred plants in each treatment formed a unit. The softwood grafting was done at monthly interval from July 2012 to December 2012.

Root stocks were raised in poly bags from fresh seeds of guava cv. 'Sardar' extracted from ripe fruits for approximately 6 to 8 months till they attained a stem diameter of 0.5 to $1.0 \mathrm{~cm}$. staggered sowing was done to get same age uniform rootstocks for softwood grafting during different months of grafting. The scion shoots (15 to $18 \mathrm{~cm}$ long) of pencil size thickness with 3 to 4 healthy buds were used for grafting. Selected scion shoots were pre-cured ten days prior to detachment. Softwood wedge grafting was performed at monthly interval as per procedure suggested by Amin (1974). The prepared grafts were covered from top by polythene cap. This cap was retained on the graft for one month or till sprouting was observed on the graft. The observation were recorded on graft-take i.e. per cent graft success and survival percentage.
The growth parameters such as number of sprouts, per cent sprouting, average length of sprout and average number of leaves were recorded at 30, 60 and 90 days after grafting. Total nitrogen and carbohydrates content of scion shoots collected during different months were determined by the standard methods (Sadasivam and Manickam, 2005). The data was statistical analysed by following procedure as suggested by Panse and Sukhatme (1978).

\section{Results and Discussion}

The details of the observation pertaining to effect of time of softwood grafting are presented in Table 1. The outcome of the present experiment highlighted that softwood grafting in guava can be successfully carried out from June to December with varying degree of success under shade house ecosystem. The interpretation of data revealed that graft success $(69.00$ and $65.50 \%)$ was high in grafting performed during December and July months. However, they were found statistically on par with one another. The graft success $(34.00 \%)$ was least in grafting performed during September. High graft success obtained during December month for softwood grafting may be attributed to the availability of naturally cured scion shoots on the mother plants during that period as it precedes with initiation of winter resulting in partial defoliation of plants and accumulation of food reserves in the scion shoots. This is confirmed by the observation of presence of high levels of carbohydrates with higher C: $\mathrm{N}$ ratio in shoots of December month (Table 2), their by making it available for new callus tissues developing at graft interface. This finding is corroborated with opinion of Chovatia and Singh (1999) in custard apple and Singh and Singh (2006) in jamun.

Similarly grafting performed in July recorded high graft take. This might be attributed to the 
reason that July month grafting coincided with the inception of monsoon with prevalence of high humidity and slightly elevated temperatures. These findings are in line with Mukherjee and Majumdar (1964) who clearly indicated the relation between time of grafting with graft success and growth of grafts with moderate temperature and moderate to high rainfall promoting callus development and rapid graft union formation. Similar findings were suggested by Sanjay et al., (1996) in mango, Madalageri et al., (1990) in sapota and Chovatia and Singh (2000) in jamun.

Table.1 Effect of season on graft-take and its growth t 90 DAG in softwood grafting of guava cv. Sardar

\begin{tabular}{|c|c|c|c|c|c|c|}
\hline Treatments & $\begin{array}{l}\text { Per cent } \\
\text { graft } \\
\text { success }\end{array}$ & $\begin{array}{c}\text { Numbe } \\
\text { r of } \\
\text { sprouts }\end{array}$ & $\begin{array}{l}\text { Per cent } \\
\text { sprouting }\end{array}$ & $\begin{array}{c}\text { Average } \\
\text { length of } \\
\text { sprout }(\mathrm{cm})\end{array}$ & $\begin{array}{l}\text { Average } \\
\text { number } \\
\text { of leaves }\end{array}$ & $\begin{array}{c}\text { Survival } \\
\text { percentage }\end{array}$ \\
\hline $\mathrm{T}_{1}(\mathrm{July}-2012)$ & $\begin{array}{c}65.50 \\
(54.03)^{*}\end{array}$ & 1.88 & $\begin{array}{c}42.53 \\
(40.72)\end{array}$ & 8.12 & 11.98 & $\begin{array}{c}94.88 \\
(76.90)\end{array}$ \\
\hline $\mathrm{T}_{2}$ (August- 2012) & $\begin{array}{c}46.50 \\
(42.99)\end{array}$ & 2.96 & $\begin{array}{c}31.14 \\
(33.87)\end{array}$ & 2.71 & 6.21 & $\begin{array}{c}83.75 \\
(66.24)\end{array}$ \\
\hline $\mathrm{T}_{3}$ (September- 2012) & $\begin{array}{l}34.00 \\
(35.67)\end{array}$ & 2.27 & $\begin{array}{c}35.70 \\
(36.69)\end{array}$ & 3.97 & 8.45 & $\begin{array}{c}67.60 \\
(55.30)\end{array}$ \\
\hline $\mathrm{T}_{4}($ October- 2012$)$ & $\begin{array}{l}48.00 \\
(43.85)\end{array}$ & 2.31 & $\begin{array}{c}34.65 \\
(36.08)\end{array}$ & 5.23 & 9.41 & $\begin{array}{c}81.50 \\
(64.52)\end{array}$ \\
\hline $\mathrm{T}_{5}($ November- 2012$)$ & $\begin{array}{c}61.00 \\
(51.35)\end{array}$ & 3.63 & $\begin{array}{c}67.25 \\
(55.11)\end{array}$ & 4.63 & 15.17 & $\begin{array}{c}89.82 \\
(71.39)\end{array}$ \\
\hline $\mathrm{T}_{6}($ December -2012$)$ & $\begin{array}{c}69.00 \\
(56.17)\end{array}$ & 4.27 & $\begin{array}{c}70.37 \\
(57.05)\end{array}$ & 5.85 & 15.90 & $\begin{array}{c}90.77 \\
(72.31)\end{array}$ \\
\hline $\mathrm{SEm} \pm$ & 3.32 & 0.20 & 3.34 & 0.46 & 0.96 & 3.30 \\
\hline CD@ @ $5 \%$ & 9.89 & 0.60 & 9.93 & 1.37 & 2.87 & 9.82 \\
\hline $\mathrm{CV}(\%)$ & 18.49 & 4.93 & 19.92 & 8.40 & 11.82 & 14.6 \\
\hline
\end{tabular}

DAG - Days after grafting

* Values in parenthesis are angular transformation data

Table.2 Effect of season on Carbohydrates: Nitrogen ratio in the scions used for softwood grafting in guava cv. Sardar

\begin{tabular}{|l|c|c|c|}
\hline \multicolumn{1}{|c|}{ Month } & $\begin{array}{c}\text { Total Carbohydrates } \\
(\boldsymbol{\%})\end{array}$ & Total Nitrogen (\%) & C:N ratio \\
\hline $\mathrm{T}_{1}$ (July-2012) & 12.07 & 0.96 & 12.65 \\
$\mathrm{~T}_{2}$ (August- 2012) & 9.60 & 0.97 & 9.91 \\
$\mathrm{~T}_{3}$ (September- 2012) & 9.33 & 0.96 & 9.69 \\
$\mathrm{~T}_{4}$ (October- 2012) & 9.18 & 0.89 & 10.32 \\
$\mathrm{~T}_{5}$ (November- 2012) & 12.60 & 0.91 & 13.82 \\
$\mathrm{~T}_{6}$ (December-2012) & 12.80 & 0.86 & 14.88 \\
\multicolumn{1}{|c|}{$\mathrm{SEm} \pm$} & 0.15 & 0.01 & 0.23 \\
$\mathrm{CD} \mathrm{@} \mathrm{5 \%}$ & 0.46 & 0.02 & 0.69 \\
$\mathrm{CV}(\%)$ & 2.76 & 1.65 & 3.74 \\
\hline
\end{tabular}


Fig.1 Monthly weather data recorded during the period of investigation

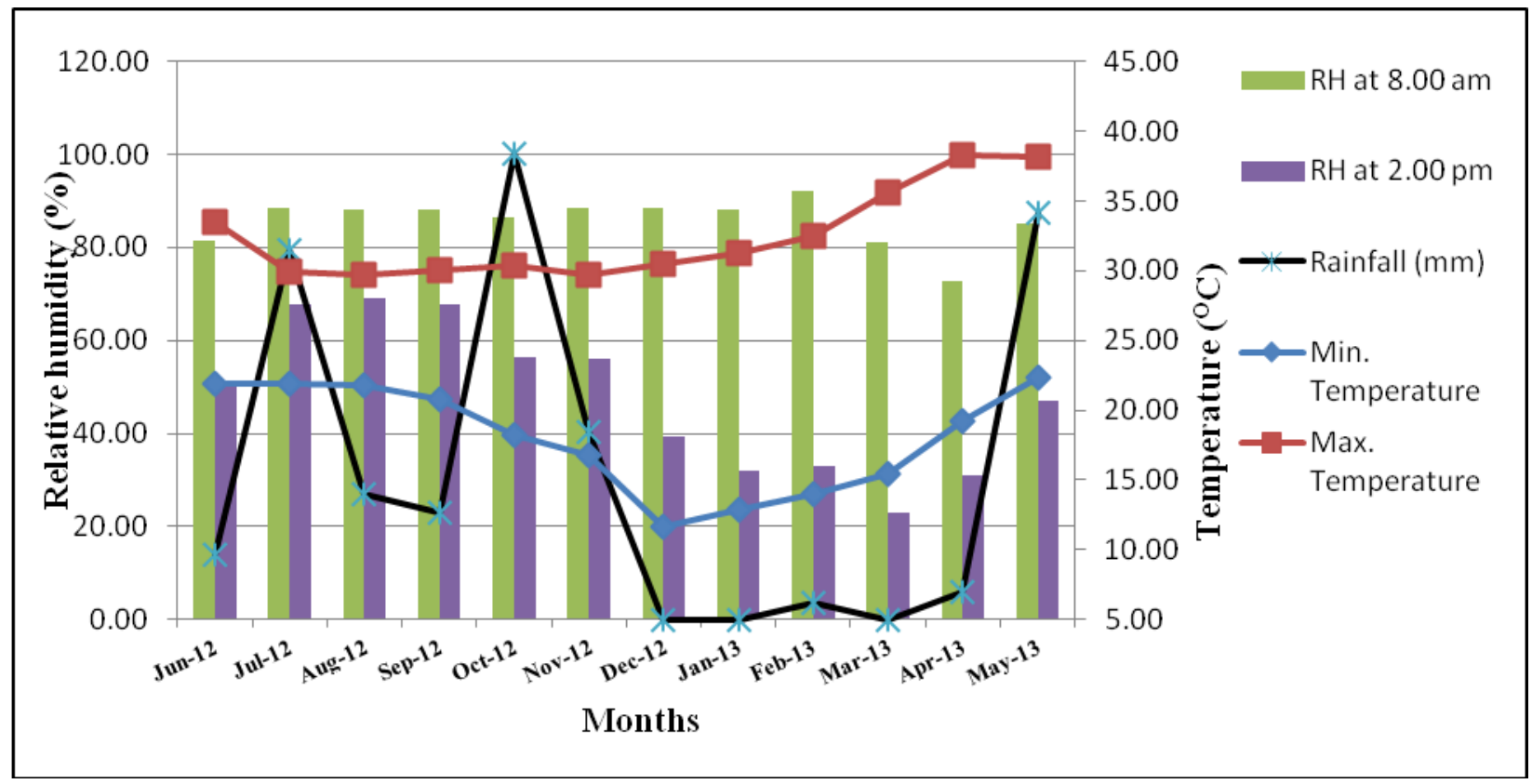

Grafts prepared in December and July months also recorded good growth during hardening. Grafts of December noted high values for number of sprouts (4.27), percent sprouting $(70.37 \%)$ and average number of leaves (15.90) at 90 days after grafting (Table 1). The post grafting growth behavior of grafts prepared during December may be attributed to the physico- chemical condition of the scion shoots which are available for developing tissues for new growth. This might have also helped in quick and strong graft union formation and better nutrient uptake. Similar findings were reported by Wazarkar et al., (2010) in sapota, Chovatia and Singh (2000) in jamun and Jacob et al., (2001) in mango.

In the present study significantly reduced graft success was noted during the September and August months in spite of prevalence of favourable climatic conditions (Fig 1). This might be attributed to the complex relation between the physico- chemical status of scion shoots and their interaction with environmental condition. During these months the plants are in reproductive phase (mrig bahar) with profuse flowering and initiation of fruit set. Therefore the scions shoots collected during these months were depleted with food reserves as depicted by lower $\mathrm{C}$ : $\mathrm{N}$ ratio status of scion shoots collected during these months (Table 2). This was also aggravated due to inadequate rainfall received during the month of August and September (Fig 1). Similar findings have been documented in other crops like sapota (Pampanna and Sulikeri, 2000) and cashewnut (Swami et al, 1990).

The graft survival percentage after 90 DAG showed significant differences among the months of grafting. Significantly high survival percentage was registered in grafts prepared during July (94.88 \%) and December (90.77\%) respectively. Good growth with higher survivability may be attributed to congenial environmental condition prevailing during post grafting hardening period which coincided with monsoon rains under Arabhavi conditions. 


\section{References}

Amin, R. S. 1974. A study on the establishment of mango orchard with wedge graft on insitu grown mango seedlings in dry region of Gujarat. Haryana J. Hort. Sci. 3: 160167.

Chovatia, R. S. and Singh, S. P. 1999. Standardization of method and time of propagation in custard apple cv. 'Sindhan local' under Saurashtra conditions. Hort. J. 12 (2): 1-7.

Chovatia, R. S. and Singh, S. P. 2000. Effect of time on budding and grafting success in jamun (Syzygium cumini Skeel). Indian J. Hort. 57 (3): 255-258.

Jacob, S. Ray, D. P. Sathu, G. S. and Chandra, A. 2001. Studies on the success of softwood grafting of some commercial hybrid mango (Mangifera indica L.). Orissa J. Hort. 29: 6-8.

Madalageri, M. B. Sulikeri, G. S. Hulamani, N. C. and Patil, V. S. 1990. Studies on greenwood wedge grafting on sapota. Paper presented at the XXII international congress, $27^{\text {th }}$ Aug- $1^{\text {st }}$ Sep. Italy.

Mukherjee, S. K. and Majumdar, P. K., 1964, Effect of different factors on the success of veneer grafting. Indian J. Hort., 21 (4): 77-79.

Pampanna, Y. and Sulikeri, G. S. 2000. Effect of season on the success and growth of softwood grafts in sapota on invigorated rayen rootstock. Karnataka J. Agric. Sci. 13 (3): 779-782.

Panse, V. G. and Ukhatne, P. V. 1978. Statistical methods for agricultural workers, ICAR, New Delhi, pp. 152-161.

\section{How to cite this article:}

Manga, B., P. Jholgiker, G.S.K. Swamy, G. Prabhuling and Sandhyarani, N. 2017. Standardization of Optimum Season for Softwood Grafting in Guava (Psidium guajava L.) cv. Sardar. Int.J.Curr.Microbiol.App.Sci. 6(5): 2814-2818.

doi: https://doi.org/10.20546/ijcmas.2017.605.317
Sadasivam, S. and Manickam, A. 2005. In Bioichemical Methods, New Age national publishers.

Sanjay, S. Sengupta, B. N. and Singh, S. 1996. Effect of time on soft wood grafting in mango cv. Amrapali. Hort. J. 9: 13-16.

Singh, S. and Singh, A. K. 2006. Standardization of method and time of propagation in jamun (Syzygium cuminii) under semi-arid environment of western India. J. Agric. Sci. 76: 242- 245.

Shashikumar, 2010. Standardization of softwood grafting in guava (Psidium gujava L). M. Sc. (Hort.) thesis, Univ. Agric. Sci. Dharwad.

Singh, G. Gupta, S. Mishra, R. and Singh, A. 2007. Technique for rapid multiplication of guava (Psidium guajava L.). Acta Hort. 735: 177-182.

Singh, C. P. Rajesh Singh. and Gopal Singh. 2005. Year around propagation of mango by cleft grafting under controlled conditions. International Conference on Plasticulture and Precision Farming. 1721 November, 2005, New Delhi. P. 71.

Swami, K. R. M. Singh, R. and Mohan, 1990. Correlation of success on softwood grafting in cashew with weather parameter. South Indian Hort. 38 (6): 297-300.

Wazarkar, S. S. Patel, H. C. Masu, M. M. Parmar, A. B. and Sitapara, H. H. 2010. Effect of grafting dates and grafting materials on softwood grafting in sapota [Manilkara achras (Mill.) Fosberg] under middle Gujarat agro climatic conditions. Asian J. Hort. 4 (2): 434-439. 